\title{
The Effectiveness of Using Teaching English for Young Learner (TEYL) Module for Pre-service Teacher Based on Teacher Training Approach
}

\author{
Nirwana Darwis ${ }^{1}$, Uswatun Hasanah ${ }^{2}$ \\ Nirwana.darwis07@gmail.com ${ }^{1}$, uswah.intan@gmail.com $^{2}$ \\ 1 Tarbiyah Faculty, IAIN Bone, Watampone, Indonesia \\ 2 Tarbiyah Faculty, IAIN Bone, Watampone, Indonesia
}

Received: 18 December 2019 Accepted: 5 May 2020

DOI: $10.24256 /$ ideas.v8i1.1022

\begin{abstract}
Teaching English for young learner by the pre-service teacher of PGMI Study Program at IAIN Bone have its challenge. One of the challenges faced by teachers is the use of learning modules that are appropriate and in accordance with the needs of students. This research is focused on the effectiveness of teaching English for Young learner (TEYL) Module based on teacher training approach. The research applied quantitative research by using rubric of students' achievement in collecting data. The subject in this research is 25 students in PGMI Study Program. In evaluating the students' achievement, the researchers use semantic differential scales. The result of the research shows that the students score that categorized good; (82.42).It mean that using the TEYL module is satisfying to be implemented in the class. Therefore,It can stated that the module is effective to use in teaching English for Young Learner (TEYL) in PGMI Study Program IAIN Bone.
\end{abstract}

Keywords: Teaching English for Young Learner (TEYL), Teaching Material, Module 


\section{Introduction}

Teaching is an amazing experience. A teacher, when doing the teaching process must go through several stages, such as preparing lesson plan, compile teaching materials, complete learning tools, determine teaching strategies appropriate to the level of students taught. Being a teacher is a challenging professional job. It is also felt by teachers who teach English for Young Learner (EYL)

English lessons in elementary school become subjects of local content. The subject of local content is one of the subjects that can be taught in primary and secondary education ${ }^{1}$. It is based on Law No. 20 of 2003 on the National Education System that is in Chapter X Article 37 which is then clarified in Government Regulation number 32 of 2013 on Amendment to Government Regulation No. 19 of 2005 on National Education Standards. (UU.No. 20:2003). Teaching English as a foreign language applies to elementary school-aged children, this is in line with those described by Steinberg that children can accept language in natural situations when the child is fewer than 7 (Steinberg, 1999:210).

At this time children can be taught knowledge about language and communication, including the teaching of foreign languages. Thus, it can be stated that English as a foreign language in Indonesia can be taught in elementary school. In teaching English, students are expected to have several competencies, one of which is communicative competence. It means that the students need to have the skills in the right situation in right situation (Wello \& Dollah, 2008:25), (Juliana 0 \& Richard K:2002)

There are special efforts that need to be made as an effort to prepare special English teachers for young learners. Teachers are required to understand the needs of their students related to linguistic competence and communicative competence which are to be achieved as an English language learning goal for young learners. Lynne Cameron comments that enthusiastic and lively as a learner (Cameron,2001:1). The ongoing teaching and learning process not only requires teachers to be able to transfer new knowledge to their students, but also to build up the positive emotion and social interaction. One way that can be done is to provide teaching material that is interesting and interactive (Anggareni, et.all: 2019). Thus teaching English as a foreign language in children has its own advantages for teachers.

The things that need to be considered and understood by the teacher are about the characteristics of young learners, about how young learners learn English, the principles of teaching English for young Learners. To achieve these, teachers need to prepare themselves before engaging in the learning process in the classroom. To support the success of the learning process, the teachers need to consider the student preference learning style in order. This is conducted in order the students can understand the material taught to them so that learning objectives 
Nirwana Darwis, Uswatun Hasanah

The Effectiveness of Using Teaching English for Young Learner (TEYL) Module for Pre-service Teacher Based on Teacher Training Approach

can be achieved (Hasanah: 2013). From the various situations, this makes the teacher to be more creative in delivering teaching materials. Teachers should prepare learning materials and activities that are fun and lively for the young learner. One of the determinants of successful teaching and learning process is the availability of appropriate teaching materials.

English for Young Learner (EYL) teacher must be able to provide teaching materials in accordance with the learning objectives to be achieved. The thing that must be considered by the teacher in preparing teaching material is the audience who will use the book. The intended audience is students and teachers (Damayanti:2014). The teacher or developers materials also need to know how effective the course is (Fadliyah: 2013). A Research done by Wanci and Darwis (2019) about Pre-Service and In-service teachers' perception on peer reflection shows the importance of the self reflection on peer teaching. Their research would be taken as a reference in TEYL module. Many ways can be done, one of which is to provide an appropriate module.

This research attempts to describe Teaching English for Learner (TEYL) module for the College students based on the teacher training approach. This would give the learners experience the theories they had in language classroom. This study analyzes the effectiveness of the TEYL Module for pre-service teachers based on the teacher training approach.

\section{Method}

\section{Research Design}

This study used descriptive quantitative research. This research used a rubric for evaluation sheet of students' achievement after teaching them by using TEYL module. The participants of the research were the fifth semester of primary School Education Program (PGMI) of IAIN Bone. This study used cluster sampling technique. There were 25 students. Before collecting the data, the students thought by using the module of TEYL for several meetings. The rubric consists of some indicators.

Table 1. Evaluation Sheet

\begin{tabular}{|c|c|c|}
\hline No & Indicators & Items \\
\hline \multirow{4}{*}{1} & \multirow{4}{*}{ Teaching skills } & sets up and manages activities effectively \\
\hline & & can accommodate different learner types \\
\hline & & adapts activities appropriately \\
\hline & & achieves learning objectives in time given \\
\hline \multirow{3}{*}{2} & \multirow{3}{*}{ Lesson Planning } & $\begin{array}{l}\text { identifies and articulates appropriate overall lesson } \\
\text { aims }\end{array}$ \\
\hline & & plans lesson with logical staging \\
\hline & & $\begin{array}{l}\text { selects and/or adapts materials and/or activities } \\
\text { suitable for the learners and the lesson objectives }\end{array}$ \\
\hline
\end{tabular}




\begin{tabular}{cll}
\hline 3 & $\begin{array}{l}\text { Lesson evaluation \& } \\
\text { reflection }\end{array}$ & $\begin{array}{l}\text { reflects critically on planning and teaching of other } \\
\text { students }\end{array}$ \\
\hline 4 & Knowledge and theory & $\begin{array}{l}\text { shows an understanding of relevant theory and } \\
\text { teaching principles }\end{array}$ \\
\hline
\end{tabular}

In evaluating the students' achievement, the researchers use semantic differential scales to measure students' abilities.

Table 2. Differential Scale of Students Achievement

\begin{tabular}{|l|l|l|l|l|l|l|}
\hline Very poor & 1 & 2 & 3 & 4 & 5 & Very Good \\
\hline
\end{tabular}

After all students score had calculated the data then converted into five categories, determined the frequency (f), and the percentage (\%). The table can be seen as follow:

Table 3. Students score Classification

\begin{tabular}{|c|c|c|}
\hline \multicolumn{3}{|c|}{ Students } \\
\hline No & Score & Category \\
\hline 1 & $85.00-100$ & Very Good \\
\hline 2 & $75.00-84.99$ & Good \\
\hline 3 & $60.00-74.99$ & Fairly Good \\
\hline 4 & $45.00-59.00$ & Poor \\
\hline 5 & $0.00-44.99$ & Very Poor \\
\hline
\end{tabular}

The next step is calculating the students mean score. The module can be considered significantly effective if the students' score is categorized good or very good.

\section{Results}

\section{Findings}

The process of collecting data was held on September 17, 2019 with 25 students taking part. Indicators of student achievement are divided into 4 sections. These indicators are skills in teaching activities, Lesson planning, evaluation and reflection, knowledge and theory. From these four indicators, it is broken down into 10 evaluation items 
Nirwana Darwis, Uswatun Hasanah

The Effectiveness of Using Teaching English for Young Learner (TEYL) Module for Pre-service Teacher Based on Teacher Training Approach

Teaching skills

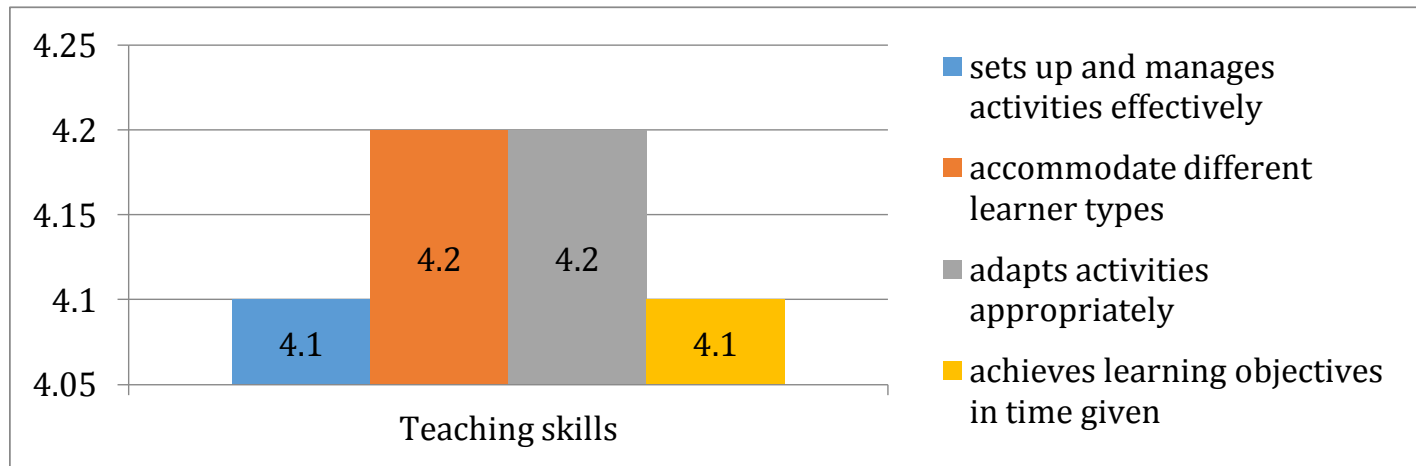

Figure 1. Students Score on Teaching Skill

Figure 1 shows that the students score based on their ability in teaching after using the TEYL module in learning process are commonly good. By seeing the differential scale, the highest score is 5 and it is stated as very good result. However, the students score in teaching skill are varied 4,1 and 4,2. The students are better in accommodating different of learner types and in adapting activities appropriately. While in setting up and managing activities effectively, the students score are lower. It is similar in item of achieving learning objectives in time given. But overall, all the students score can be stated in good achievement.

\section{Lesson Planning}

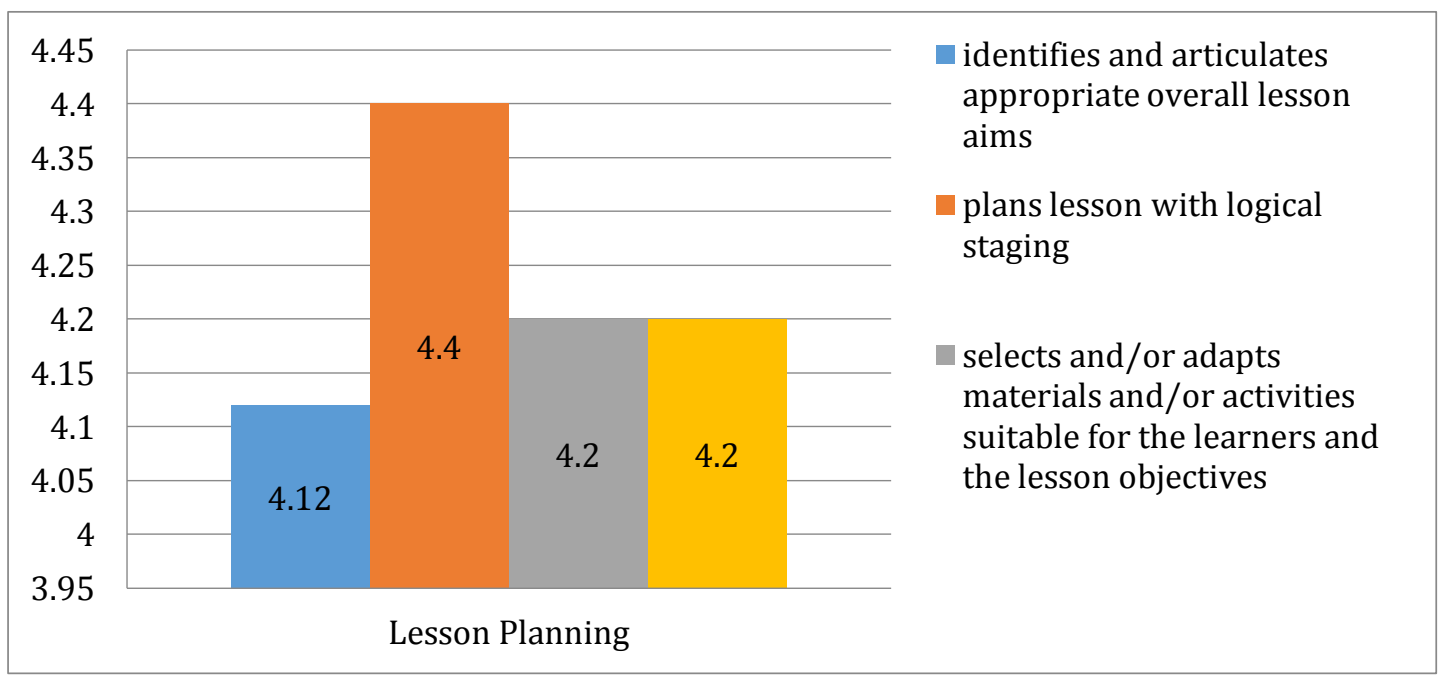

Figure 2. Lesson Planning

The result of the students score in planning the lesson can be seen in figure 2 above. The data shows that the highest score is in planning lesson plan with logical staging. Besides that, there are two item have similar score. They are the students' achievement in selecting or adapting material or activities suitable for 
the learners and the lesson objectives. The lowest score is assigning realistic timing to the stages in the lesson. But overall, student achievement is remaining good in the lesson planning category.

\section{Evaluation and Reflection}

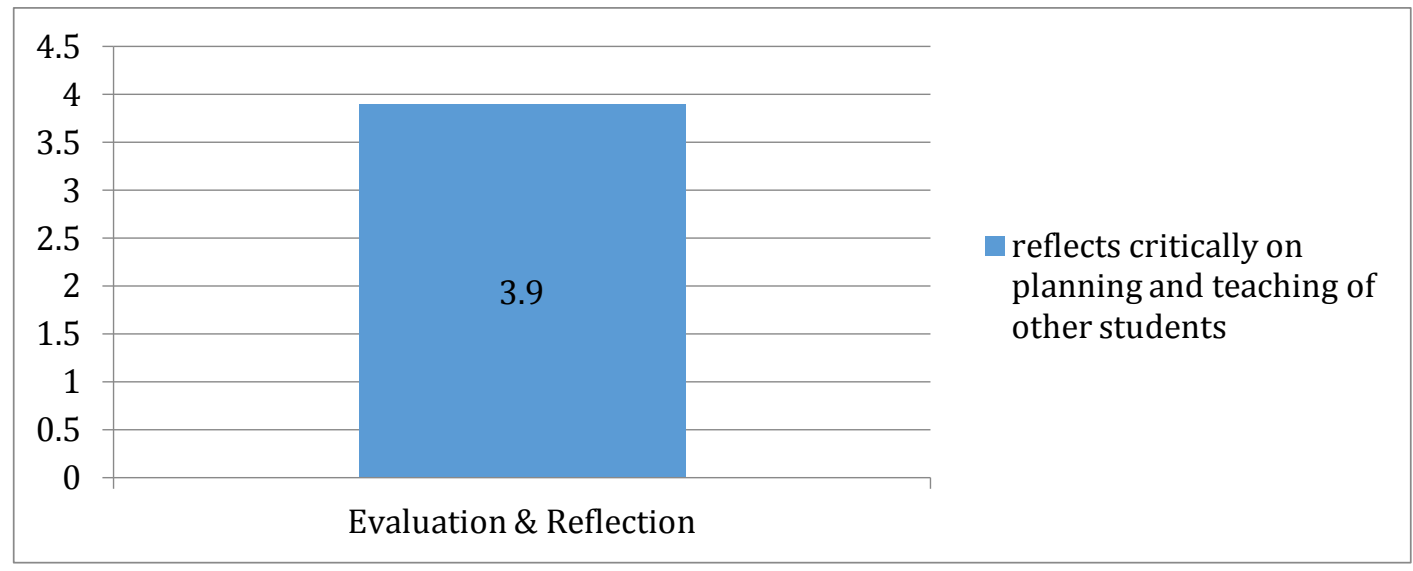

Figure 3. Students score on Evaluation and Reflection Activity

After teaching the students by using TEYL module, the researchers evaluate the students' achievement. It is conducted to verify the use of TEYL module. One item to measure the students' achievement is scoring their ability in conducting evaluation and reflection after teaching practice. The result shows that the average score is categorized fairly poor. It means that TEYL module has not been able to encourage students' ability significantly in conducting evaluation and reflection in the process of teaching English for young learners.

Knowledge and Theory

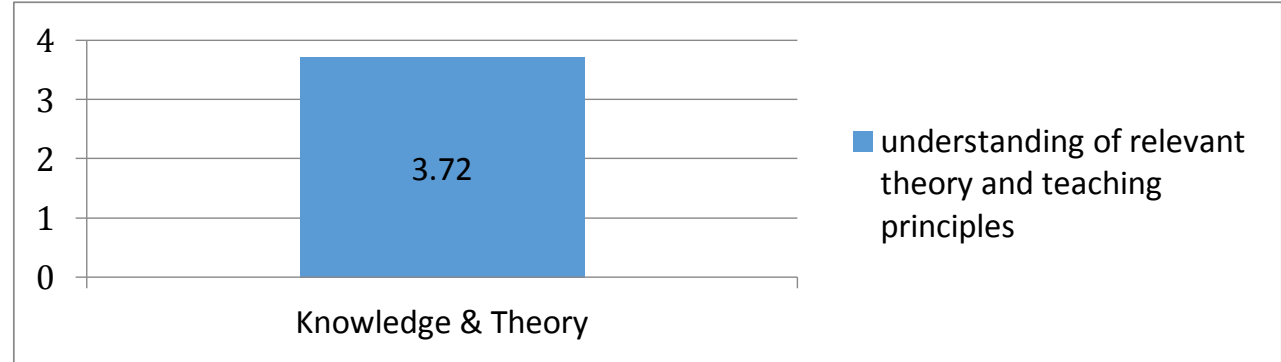

Figure 4. Students Score on Knowledge and theory

The last indicator in this evaluation sheet of students' achievement is related knowledge and theory. The figure shows that the students score is 3,72 . It means that the students have fairly poor achievement related to the knowledge and theory.

After analyzing the items based on the indicators of students' achievement in learning by using the TEYL module, the researcher then classify the students score 
Nirwana Darwis, Uswatun Hasanah

The Effectiveness of Using Teaching English for Young Learner (TEYL) Module for Pre-service Teacher Based on Teacher Training Approach

into five category of achievement. The result can be seen as follow:

Table 4. Students' Score Classification

\begin{tabular}{|c|c|c|c|c|}
\hline & Students & & & \\
\hline No & Score & Category & f & $\%$ \\
\hline 1 & $85.00-100$ & Very Good & 7 & $28 \%$ \\
\hline 2 & $75.00-84.99$ & Good & 18 & $72 \%$ \\
\hline 3 & $60.00-74.99$ & Fairly Good & 0 & $0 \%$ \\
\hline 4 & $45.00-59.00$ & Poor & 0 & $0 \%$ \\
\hline 5 & $0.00-44.99$ & Very Poor & 0 & $0 \%$ \\
\hline \multicolumn{3}{|c|}{ TOTAL } & 25 & $100 \%$ \\
\hline \multicolumn{3}{|c|}{ Mean Score } & & 82,48 \\
\hline
\end{tabular}

The table 4 above shows that the students score spread into only tow category. They are $72 \%$ students achieve good score and while $28 \%$ students achieve very good rank. While no one student was classified in the lower category. Based on the results of the analysis of student achievement, the mean score of students achievement is $82,48 \%$. Based on the qualification guidelines for students' ability scores, the mean score is classified good category.

\section{Discussion}

Based on the description of the data analysis above, a TEYL Learning Material Based on Teacher Training Approach was arranged to improve the Achievement of PGMI students in English Learning Courses. And to measure the effectiveness of the module developed, the researcher analyze it by assessing the students' achievement after teaching them using TEYL Module.

The product (TEYL Module) developed was then trialed to 25 PGMI IAIN Bone students. The effectiveness of the learning modules developed can be seen from the percentage of students' mastery learning. The completeness of student learning comes from the achievement test scores conducted by researchers at the evaluation stage.

In evaluating the students' achievement after teaching by using the module, there are four indicators evaluated. They are teaching skills, planning lesson, evaluation and reflection, and knowledge and theory. All indicators measure by using differential scale 1 to 5 . All four indicators break down into 10 items. The lowest score was marked by point 1 and highest score was marked by point 5 .

The first indicator is the performance of students' teaching practice. In the module, the students teach about how to set up and manage the activity that suitable for young learner. The other component in the module is promoting the different types of students' preference learning style. And then the students determine kinds of activity that can be adapted during the learning process. Besides that, the pre-service teacher also teaches how to achieve learning 
objectives in time given.

Based on the students' achievement after teaching by using the TEYL model based on teacher training approach, it can be seen that most students have good score. All items in these indicators are good result. The students got the point 4,1 and 4,2 in each component. It means that the module have covered the pre service teacher need related to teaching performance.

The other indicator in evaluating the pre-service teacher achievement is the ability in arranging Lesson Planning. Before conducting teaching practice, the pre-service teacher should arrange a lesson planning as guidance in delivering teaching material. The TEYL Module provides material about how to arrange lesson plan. In the module, the pre service teachers are guided to identify and articulate appropriate overall lesson plan, plans lesson with logical staging, selects or adapts material and activities suitable for young learner, and assigns realistic timing to the stages in the lesson.

After teaching by using TEYL module, the students score shows good result. Among four items evaluated, the students get score 4,12;4,4 and 4,2. It means that the students have good achievement in arranging lesson plan after teaching by using TEYL Module. One of the keys to successful teaching practices is readiness in designing learning. Feelings of unpreparedness tended to cluster around a few common challenges such as meeting the needs of high-poverty student populations and responding to insufficient resources (Kuriloff, P., Jordan, W., Sutherland, D., \& Ponnock, A.:2019). Therefore, pre service teachers for Young learners need to be given basic knowledge of the steps of preparing lesson planning that is appropriate to the needs of students and according to the learning objectives to be achieved.

There two others indicators in evaluating the pre-service teacher achievement after using TEYL Module. They are Evaluation and Reflection; and understanding and theory. There are three stages in teaching. There are planning, implementation and evaluation. The pre-service teachers also conducted evaluation and reflection. It is to teach the pre-service teacher measuring the success of their teaching. This research shows that the pre-service teacher got score 3,9 . In can be categorized fairly good. It means that the module should be modified more to promote the students on reflecting critically on planning and teaching of other students. A pre-service teacher, it is very important for them to be able to reflect after teaching practice (Sutherland, L., Howard, S., \& Markauskaite, L.:2010). This will be additional information for them in supporting aspects of their professionalism as teachers

The other indicator is knowledge and theory. The pre-service teacher score is 3,72 . It has the same category on the pervious indicator, fairly good. By seeing this result, it means that the module should be improved more on teaching the theory and knowledge of the students related to understanding of relevant theory and teaching principle to English young learner. 
Nirwana Darwis, Uswatun Hasanah

The Effectiveness of Using Teaching English for Young Learner (TEYL) Module for Pre-service Teacher Based on Teacher Training Approach

Even though the last two indicators shows lower score, but overall are good. Based on the table above the average value of students' mastery learning are 82.42. It shows that learning by using TEYL learning material module based on teacher training approach has fulfilled the effectiveness aspect. The use of TEYL modules for pre-service teachers in PGMI students makes a significant contribution. A good module can help students overcome problems that are sometimes encountered in the learning process. The TEYL module provides materials needed by PGMI students in preparing themselves to teach English for young learners. By using the TEYL module, this learning problem could be overcome by providing a conducive learning environment based on problem solving, working by pairs, the construction of concept maps and brainstorming (Matanluk, O., Mohammad, B., Kiflee, D. N. A., \& Imbug, M.:2013).

Based on the analysis, the results of student achievement tests can be concluded that learning using TEYL learning material modules based on teacher training approaches is effectively used as one of the teaching materials for English Learning Courses in Study Program of PGMI IAIN Bone.

\section{Conclusion}

After conducting this research and showing the data and discussion above, it can be concluded that using TEYL Module for Pre-service teacher based on teacher training approach is effective to students of PGMI Study Program IAIN Bone. It can be seen from the students score that categorized good; (82.42). Yet there are more items that suppose to be encourage for the next module. There are a number of things that still need to be revisited regarding the TEYL module. So that later TEYL modules will be produced that fit the needs of PGMI IAIN Bone students.

\section{References}

Anggreni, A. (2019). Analyzing Teachers' Praise In Classroom Interaction. IDEAS: Journal on English Language Teaching and Learning, Linguistics and Literature. Volume 7, Number 2, December 2019. pp. 221- 232. Retrieve from https://ejournal.iainpalopo.ac.id/index.php/ideas/article/view/1037/773

Cameron, L (2001). Teaching Languages to Young Learners. Cambridge: Cambridge University Press.

Cephe, P and Teflik, G (2001). Learner variables in learning English, MET 10 (1), 57-62.

Darwis, N. (2003). Reflecting Teaching in In-service Teacher Training: An Experience Being an ELTIS Trainer In Watampone. Paper Presented at TESIC International Conference, Johor, Malaysia. 
Juliana $O$ and Richard K. (2018) Pre-service Teachers' Beliefs and Practices in Teaching English to Young Learners. Doi: dx.doi.org/10.17509/ijal.v6i1.2661.

Lynne, C. (2001). Teaching Languages to Young Learners. UK: Cambrigde University Press.

Kuriloff, P., Jordan, W., Sutherland, D., \& Ponnock, A. (2019). Teacher preparation and performance in high-needs urban schools: What matters to teachers. Teaching and Teacher Education, 83, 54-63. doi:10.1016/j.tate.2019.04.001

Masruddin, M. (2018). The Efficacy of Using Short Video through Group Work in Teaching Speaking to Indonesian English as Foreign Language (EFL) Students. Arab World English Journal, 9 (3), 282-293. DOI: https://dx.doi.org/10.24093/awej/vo19no3.19

Masruddin, M., \& Sander, A. (2019). The Efficacy of Pre Service English Teacher Training Camp towards Students' English Teaching Skills. Asian EFL Journal. 21(2.3). 200-215

Matanluk, O., Mohammad, B., Kiflee, D. N. A., \& Imbug, M. (2013). The Effectiveness of Using Teaching Module based on Radical Constructivism toward Students Learning Process. Procedia - Social and Behavioral Sciences, 90, 607-615. doi:10.1016/j.sbspro.2013.07.132

Mooney, S.T et all. (2016). Peer Assessment as a Teaching and Learning Process: The Observations and Reflections of Three Facilitators on a First-Year Undergraduate Critical Skills Module. All Ireland Journal of Teaching and Learning in Higher Education (AISHE-J). 8(2). 2831-28318.

Peraturan Pemerintah Nomor 32 tahun 2013 tentang Perubahan Atas Peraturan Pemerintah Nomor 19 tahun 2005 tentang Standar Nasional Pendidikan.

Rahmah, F. (2018). Development Learning Material ESP. IDEAS: Journal on English Language Teaching and Learning, Linguistics and Literature, 1(1). doi:https://doi.org/10.24256/ideas.v1i1.127

Sri, D. (2018). Designing Multimedia for Lecturers Need in Teaching English Pronunciation. IDEAS: Journal on English Language Teaching and Learning, Linguistics and Literature, 2(2). doi:https://doi.org/10.24256/ideas.v2i2.33

Steinberg, D. D. (1999). An Introduction to Psikolinguistics. New York, Longman.

Sutherland, L., Howard, S., \& Markauskaite, L. (2010). ProfessionaI Identity Creation: Examining the Development of Beginning Preservice Teachers' Understanding of their Work as Tteachers. Teaching and Teacher Education, 26(3), 455-465. doi:10.1016/j.tate.2009.06.006

Undang-undang Nomor 20 tahun 2003 tentang Sistem Pendidikan Nasional

Uswatun, H. (2018). Autonomous Learning as Language Learning Strategy Based on

Students Preferenced Learning Style. IDEAS: Journal on English Language Teaching and Learning, Linguistics and Literature, 1(2). doi:https://doi.org/10.24256/ideas.v1i2.163 
Nirwana Darwis, Uswatun Hasanah

The Effectiveness of Using Teaching English for Young Learner (TEYL) Module for Pre-service Teacher Based on Teacher Training Approach

Wanci, R and Darwis, N (2019). Analyzing In-Service and Pre-Service Teachers' Perceptions on Peer Reflection at IAIN Bone. Asian EFL Journal. 23(3.4). 448-459

Wello,B., Dollah, S (2008). Fundamental Aspect of English for Specific Purposes. Makassar: Badan Penerbit UNM. 